\title{
Adsorption of serum calcium by plastic sample cups
}

\author{
R. A. HALL AND T. P. WHITEHEAD \\ From the Department of Biochemistry, Queen Elizabeth Hospital, Birmingham
}

SYNOPSIS Sera left overnight in plastic AutoAnalyzer sample cups may give low calcium values; the effect is attributed to adsorption of calcium onto the walls of the vessel. The adsorption is brought about by a rise in the $p \mathrm{H}$ of the sera, and factors which promote the rise in $p \mathrm{H}$ increase the adsorption. This phenomenon is of practical importance because as much as $10 \%$ of the calcium in the serum may be adsorbed.

Adsorption occurs particularly onto the walls of polystyrene cups, and when polypropylene cups were used the adsorption was reduced.

The phenomenon cannot be evaluated or controlled by the use of control sera. In order to avoid the sampling error, serum for calcium analysis should be used fresh or stored at $4^{\circ} \mathrm{C}$ under conditions such that any change in $p \mathrm{H}$ is minimal. Sera should not be left to stand in AutoAnalyzer cups at room temperature for longer than three hours before analysis.

Varley (1967) stated that from time to time several AutoAnalyzer techniques for serum calcium gave falsely low values. After the routine introduction of the Technicon N-3A methodology for serum calcium into our laboratory, it was discovered that daily mean values for serum calcium were, on occasion, spuriously low, confirming Varley's findings. After many preliminary experiments the error was identified as one of sampling. It was found that under certain conditions low results were obtained in sera which had been left to stand in the plastic sample cups normally used in the AutoAnalyzer.

Hill (1965) reported that low results could be obtained for serum calcium if serum is allowed to stand overnight in AutoAnalyzer cups, and a note to this effect is present in the Technicon N-31P methodology for serum calcium. In a personal communication, Hill (1968) stated that the effect was not reproducible.

In this paper the conditions necessary to reproduce the effect consistently and an investigation into the factors responsible are described. A possible explanation of the phenomReceived for publication 9 December 1969. enon is suggested and the sampling conditions required to prevent the error are described.

\section{Method}

Serum calcium was determined by a modified Technicon N-3A method, the major modification being the addition of a $20-\mathrm{ft}$ time delay coil immediately before colorimetric analysis. A precision of $\pm 0.13 \mathrm{mg}$ per $100 \mathrm{ml}$ (SD) at a serum calcium level of $10 \mathrm{mg}$ per $100 \mathrm{ml}$ was achieved. The experiments described were conducted in polystyrene AutoAnalyzer cups.

\section{Experimental}

During the introduction of automated techniques for routine serum calcium estimation, a comparison was made with the microtitration technique of Hasselman and Van Kampen (1958). It was demonstrated that, although freshly taken 
serum gave results which compared well by the two methods, low results were obtained by the automated technique, if sera were allowed to stand in the AutoAnalyzer sample cups overnight. At this stage the effect was sporadic, and on occasion the phenomena could only be seen in a few sera in a batch. The error could not be demonstrated in the available commercial control sera. Table I gives examples of sera which did show a fall: the degree of fall was variable. Further experiments were performed to show the effects of various factors on the sampling error.

\begin{tabular}{lcc}
\hline Serum No. & $\begin{array}{l}\text { Original Value } \\
(\mathrm{mg} / 100 \mathrm{ml})\end{array}$ & $\begin{array}{l}\text { Value after Standing } \\
\text { Overnight }(\mathrm{mg} / 100 \mathrm{ml})\end{array}$ \\
\hline 1 & 10.0 & $9 \cdot 2$ \\
2 & $9 \cdot 4$ & $8 \cdot 8$ \\
3 & $9 \cdot 75$ & $9 \cdot 2$ \\
4 & 11.5 & $10 \cdot 25$ \\
5 & 8.6 & 7.9 \\
\hline
\end{tabular}

Table I Comparison of results obtained on fresh sera and after standing overnight in sample cups (AutoAnalyzer technique)

Under controlled conditions of sampling the between-batch precision of the technique was $\pm 0.13 \mathrm{mg} / 100 \mathrm{ml}$ (SD). All values after standing overnight had results more than 3 SD lower than the original result.

It was soon realized that the conditions under which the specimens were stored overnight had an important bearing on the final result. If the containers were open, or merely covered by a glass plate or loosely capped, there was a considerable reduction in the serum calcium level. Such storage could, theoretically, lead to an increase in serum calcium levels because of the evaporation which occurs even at normal temperature, and as the phenomenon observed was a reduction in serum calcium levels on storage, the actual reduction in serum could be even higher than that observed. Experiments using various methods of storing the sera overnight showed that evaporation, even when the cup was covered by a glass plate, could be as high as $16 \%$. However, the phenomenon, although generally associated with evaporation, was not dependent on it, because a fall in calcium level could be shown to occur, in certain circumstances, when the evaporation was less than $3 \%$. This was accomplished by using a loosely fitting plastic cap on the sample cups.

The following experiment indicated that the 'lost' calcium could be eluted from the walls of the plastic cup. The sampling error was allowed to occur in 18 different specimens of sera, while standing overnight, during which time the $p \mathrm{H}$ rose due to a loss of $\mathrm{CO}_{2}$. Analysis was performed before and after the loss of calcium ${ }^{c}$ The mean serum calcium level before standing: was $10.3 \mathrm{mg} / 100 \mathrm{ml}$. After overnight standingo and increase in $\mathbf{p H}$ the mean serum calciuns adjusted for approximately $2 \%$ evaporation wa오․ $9.5 \mathrm{mg} / 100 \mathrm{ml}$, a loss of $0.8 \mathrm{mg} / 100 \mathrm{ml}$. Each: cup contained exactly $1.0 \mathrm{ml}$ of serum before standing overnight. After analysis the nex morning, the cups were aspirated dry and the serum was replaced by exactly $1.0 \mathrm{ml}$ of an aciẹ standard calcium solution, containing $10 \mathrm{mg} \not{\Phi}$ $100 \mathrm{ml}$ calcium and with a $\mathrm{pH}$ below $2 \cdot 0$. Analysi⿸户 of this calcium standard for each cup then gave. a mean analysis of $10.5 \mathrm{mg} / 100 \mathrm{ml}$. This indicates that the standard eluted the equivalent of $0 \cdot \overrightarrow{\psi_{j}}$ $\mathrm{mg} / 100 \mathrm{ml}$ of calcium from the walls of the cup? Cups used to store 18 specimens of serum in क्क manner that prevented a rise of $p \mathbf{H}$ did noin increase the calcium content of the standard solution.

This technique of elution was used to investitis gate the effects of various factors on the phenom? enon in preference to measuring the fall incalcium level of stored serum and correctin 8 for evaporation. In Tables II, III, and IV the amount adsorbed from the sera in $\mathrm{mg} / 100 \mathrm{mdo}$ is described as the calculated reduction in serumb calcium.

\begin{tabular}{|c|c|c|c|}
\hline $\begin{array}{l}\text { Cup } \\
\text { No. }\end{array}$ & $\begin{array}{l}\text { Temperature of } \\
\text { Storage }\left({ }^{\circ} \mathrm{C}\right)\end{array}$ & $\begin{array}{l}\text { pH of Sample } \\
\text { after Standing } \\
\text { Overnight }\end{array}$ & $\begin{array}{l}\text { Calculated Reductio } \\
\text { in Serum Calcium } \\
(\mathrm{mg} / 100 \mathrm{ml})\end{array}$ \\
\hline 1 & $26^{\circ} \mathrm{C}$ & $8 \cdot 85$ & $1 \cdot 5$ \\
\hline 2 & $26^{\circ} \mathrm{C}$ & 8.83 & $1 \cdot 5$ \\
\hline 3 & $20^{\circ} \mathrm{C}$ & $8 \cdot 72$ & $1 \cdot 1$ \\
\hline 4 & $20^{\circ} \mathrm{C}$ & $8 \cdot 75$ & $1 \cdot 3$ \\
\hline 5 & $4^{\circ} \mathrm{C}$ & $8 \cdot 18$ & \\
\hline 6 & $4^{\circ} \mathrm{C}$ & $8 \cdot 25$ & $<0.2$ \\
\hline
\end{tabular}

Table II Results of an experiment to show the influence of temperature on extent of reduction of serum calcium standing overnight ${ }^{1}$

'The same serum was used throughout the experiment and the original $p H$ was $7 \cdot 5$.

${ }^{2}$ By elution into acid standard calcium solution.

\begin{tabular}{|c|c|c|}
\hline $\begin{array}{l}\text { Time of Standing } \\
\text { (hours) }\end{array}$ & Final $\mathrm{p} H$ & $\begin{array}{l}\text { Calculated Reduction in } \\
\text { Serum Calcium }(\mathrm{mg} / 100 \mathrm{ml}\end{array}$ \\
\hline 50 & $8 \cdot 80$ & 1.4 \\
\hline 50 & $8 \cdot 82$ & 0.9 \\
\hline 29 & $8 \cdot 75$ & 1.4 \\
\hline 29 & $8 \cdot 80$ & $1 \cdot 3$ \\
\hline $7 \cdot 5$ & $8 \cdot 60$ & 0.7 \\
\hline $7 \cdot 5$ & $8 \cdot 60$ & $0 \cdot 7$ \\
\hline 3.0 & $8 \cdot 33$ & $0 \cdot 15$ \\
\hline 3.0 & $8 \cdot 33$ & 0.15 \\
\hline 1.0 & 8.05 & 0.1 \\
\hline $1 \cdot 0$ & 8.08 & $0 \cdot 1$ \\
\hline
\end{tabular}

Table III Results of an experiment to show effect of time on sampling error ${ }^{1}$

${ }^{1}$ The same serum was used throughout the experiment and the original $\mathrm{pH}$ was $7 \cdot 5$.

'By elution into acid standard calcium solution. 


\begin{tabular}{lll}
\hline $\begin{array}{l}\text { Volume of Serum } \\
\text { in Cup }(\mathrm{ml})^{2}\end{array}$ & $\begin{array}{l}\text { Final } \mathrm{pH} \text { of Serum } \\
\text { after Overnight Stand }\end{array}$ & $\begin{array}{l}\text { Calculated Reduction } \\
\text { in Serum Calcium } \\
(\mathrm{mg} / 100 \mathrm{ml})^{3}\end{array}$ \\
\hline 2.0 & 8.42 & 0.75 \\
2.0 & 8.45 & 0.55 \\
1.5 & 8.50 & 0.9 \\
1.5 & 8.52 & 1.0 \\
1.0 & 8.75 & 1.65 \\
1.0 & 8.75 & 1.6 \\
0.6 & 8.85 & 2.15 \\
0.6 & 8.85 & 1.85 \\
\hline
\end{tabular}

Table IV Results of an experiment showing effect of volume of serum aliquot placed in AutoAnalyzer cup on sampling error ${ }^{1}$

${ }^{1}$ The same serum was put into each cup and the original $p H$ was $7 \cdot 5$.

'This was also the volume of standard solution added to the cup after aspiration.

${ }^{3}$ By elution into acid standard calcium solution.

\section{EFFECT OF $p$ H}

Hydrogen ion concentration plays an important role in the sampling error and it was difficult to dissociate this factor from the other factors investigated. Freshly separated serum has a $p \mathrm{H}$ close to $7 \cdot 5$. On standing open to the air, serum loses carbon dioxide and the $p \mathrm{H}$ rises. This increase in $p \mathrm{H}$ is affected by temperature because of the associated change in solubility resulting in reduced loss of carbon dioxide at lower temperatures. It is also influenced by the time because the loss of carbon dioxide is comparatively slow. The loss of carbon dioxide is also influenced by the volume of the serum in the cup. The lower the volume of serum in the cup, the greater is the ratio of surface to volume and the quicker the fall in $p H$. Tables II, III, and IV show the effects of temperature, time, and sample volume on the sampling error. Adsorption was proportional to time and temperature but inversely proportional to sample volume. It will be seen from the Tables that it was difficult to dissociate such changes from the changes in $p \mathrm{H}$ which occurred at the same time. Three different sera were used in these experiments but the same serum was used throughout one experiment. In all three experiments the serum calcium levels were originally within the range $9 \cdot 0-10 \cdot 0 \mathrm{mg} / 100 \mathrm{ml}$.

If the temperature, time, and volume in the cup were varied they had no influence on the sampling error, provided the $p \mathrm{H}$ remained at the low figure usually found on a fresh specimen.

A method of storage which preserved the $p \mathrm{H}$ of specimens at 7.6 ensured that a result not significantly different from that found on fresh serum could be obtained. The most effective way of ensuring this was to store sera in containers with tightly fitting caps. Table $\mathrm{V}$ shows the results on sera stored in this way compared with those stored under conditions which allowed the $p \mathrm{H}$ to rise.

\begin{tabular}{llll}
\hline Sample No. & $\begin{array}{l}\text { Conditions of Storage } \\
\text { Overnight }\end{array}$ & $\begin{array}{l}\text { pH after } \\
\text { Storage }\end{array}$ & $\begin{array}{l}\text { Serum Calcium } \\
(\mathrm{mg} / 100 \mathrm{ml})\end{array}$ \\
\hline 1 & Loosely capped & 8.7 & 8.7 \\
& Tightly capped & 7.6 & 9.8 \\
& Loosely capped & 8.65 & 9.7 \\
3 & Tightly capped & 7.7 & 10.2 \\
& Loosely capped & 8.8 & 9.7 \\
& Tightly capped & 7.6 & 10.2
\end{tabular}

Table $\mathrm{V}$ Results of an experiment to demonstrate the effect of storing sera in AutoAnalyzer cups loosely and tightly capped ${ }^{1}$

${ }^{1}$ The experiment was conducted at room temperature.

\section{EFFECT OF MIXING}

If a high serum $p \mathrm{H}$ had been reached and $\mathrm{a} \stackrel{\vec{\omega}}{\mathrm{\omega}}$ long period of standing had taken place, calciumo loss could not be reversed even by vigorousin mixing of the specimen.

EFFECT OF THE TYPE OF AUTOANALYZER CUP USED

Three types of AutoAnalyzer cup were ob-? tained, made of polystyrene, glass, and poly $<$ propylene, of very similar size and shape. $\overrightarrow{0}$ Sera were left to stand overnight in the differento cups and the 'lost' calcium was determined by elution in the usual manner. The results of one of the experiments is shown in Table VI. Polypropylene was found to contain less calciumo for elution, whilst the results for glass and polystyrene cups were always very similar.

\begin{tabular}{|c|c|c|c|}
\hline Type of Cup & $\begin{array}{l}\text { Volume of Sera } \\
\text { Placed in Cup } \\
(\mathrm{ml})\end{array}$ & Final pH & $\begin{array}{l}\text { Calculated Reductio } \\
\text { in Serum Calcium }\end{array}$ \\
\hline Polystyrene & $\begin{array}{l}0.8 \\
0.8\end{array}$ & $\begin{array}{l}8 \cdot 7 \\
8 \cdot 75\end{array}$ & $\begin{array}{l}0.6 \\
0.65\end{array}$ \\
\hline Polypropylene & $\begin{array}{l}0.8 \\
0.8\end{array}$ & $\begin{array}{l}8 \cdot 75 \\
8 \cdot 75\end{array}$ & $\begin{array}{l}0.2 \\
0.4\end{array}$ \\
\hline Glass & $\begin{array}{l}0.8 \\
0.8\end{array}$ & $\begin{array}{l}8.8 \\
8.7\end{array}$ & $\begin{array}{l}0.65 \\
0.8\end{array}$ \\
\hline
\end{tabular}

Table VI Effect of type of AutoAnalyzer cup on the sampling error

${ }^{2}$ Determined by elution with an acid standard calcium solution.

EFFECT OF LIPOLYSIS

In order to investigate the effect of lipolysis quinine was added to some aliquots of serum? before setting to stand, while control sera were 0 also put up in the same manner without anyo quinine added. It was found impossible tof demonstrate that quinine, an inhibitor of lipolysis, had any effect on the results obtained

LIPID LAYERING

Complete aspiration of the sera, after standing in the cup overnight, to dryness by the Auto:- 
Analyzer sample probe did not result in a high result as the bottom of the cup was sampled. In fact, a constant result was obtained throughout aspiration.

CONFIRMATION OF THE EFFECT AS A TRUE 'SAMPLING ERROR'

The experimental work so far described was performed by an AutoAnalyzer technique. In order to confirm that the effect observed was a true 'sampling error', the EDTA microtitration technique was used to analyse serum set to stand overnight. The results were compared with those obtained on aliquots of serum kept at a $p \mathrm{H}$ below 8 . The differences between the results obtained were greater than $\pm 3 \mathrm{SD}$ of the method $(0 \cdot 15 \mathrm{mg} / 100 \mathrm{ml})$.

\section{Discussion}

At first, the most likely explanation of the reduction of serum calcium appeared to be a precipitation of calcium carbonate at the higher $p \mathrm{H}$. This would result in a deposition of calcium on the sides and bottom of the cup away from the sample probe. This explanation was disproved by two experiments. First, mixing the specimen just before sampling did not reverse the effect. Secondly, complete aspiration of the cup to dryness by the AutoAnalyzer sample tube did not result in a higher result as the bottom of the cup was sampled. In fact, a constant result was obtained throughout aspiration. This experiment also disproved any explanation based upon liquid 'layering'.

Lipolysis, resulting in increased amounts of calcium soaps, was also a possible explanation; the complete aspiration experiment showed no signs of calcium soap precipitation and inhibition of lypolysis by the addition of quinine to serum was without effect on the sampling error.

It is postulated that the sampling error is due to adsorption of calcium from the serum by the plastic cup. The adsorption theory is supported by the following two facts. First, after complete aspiration of serum from the cup after the sampling error had occurred, part of the 'lost' calcium could be eluted from the walls by an acid calcium standard. Secondly, the sampling error varied with the type of plastic used to make the cups.

As the $p \mathrm{H}$ of serum rises, the amount of ionized calcium in the serum will fall (Katz and Klotz, 1953); there will also be a tendency for the calcium salts to become insoluble. Katz and Klotz found that between a $p \mathrm{H}$ of 7.4 and 8.0 the calcium becomes bound reversibly to the albumin fraction in serum. However, they noted that between a $p \mathrm{H}$ of 8.0 and 8.8 the calcium binding by the albumin fraction was only slightly increased, and stated that thio effect was probably due to configurationa changes in the protein molecule as the $p \mathrm{H}_{0}$ rises. The increased affinity for cationic calciun may be attributed to a separation of hydroxylie. and carboxylic residues of albumin. Such $\overrightarrow{\mathrm{z}}$. separation would reduce the affinity of each site for the calcium cation and counterbalance the electrostatic attraction due to the rise in $p \mathrm{H}_{\bar{\sigma}}$.

The phenomenon of adsorption of calciun onto the walls of plastic AutoAnalyzer cups may well be related to the findings of Katz and Klotz that there is little uptake of calcium b $\vec{b}$ the albumin after a $p \mathrm{H}$ of $8 \cdot 0$. No adsorptionwas shown to have occurred before sera had reached a $p \mathrm{H}$ of 8.2 ; adsorption was onls: appreciable after sera had been standing fo $P$ some time above a $\mathrm{pH}$ of $8 \cdot 5$.

It is therefore postulated that the mechanisne of the adsorption process is as follows. Between a $p \mathrm{H}$ of $7 \cdot 4$ and $8 \cdot 0$, the ionized calcium leve falls, the calcium being taken up by protein? Above a $p \mathrm{H}$ of 8.0 uptake by the albumin fraction of sera is negligible, but there is stilitw an increasing tendency for the calcium salts to come out of solution on the walls of the cup.

\section{Conclusion}

Before this work was done our routine tech $\frac{2}{2}$ niques for collection and storage of specimens for serum calcium could, on occasion, have resulted in sera of high $p \mathbf{H}$ being stored in the sample cups, and hence low results on certain days.

In order to prevent this source of error serå should be stored at $4^{\circ} \mathrm{C}$. Storage at this temperature reduces the rise in $p \mathrm{H}$ of the sera. If stored in AutoAnalyzer cups, at least $0.6 \mathrm{mP}$ of serum should be placed in the cup which must be firmly capped and stored at $4^{\circ} \mathrm{C}$. The sera should not be removed from the refrigerator until just before analysis.

References

Hasselman, J. J. F and van Kampen, E. J. (1958). Magnesium Clin. chim. Acta, 3, 305-319.

Hill, H. B. (1968). Personal communication.

Katz, S., and Klotz, I. M. (1953). Interactions of calcium with serum albumin. Arch. Biochem., 44, 351-361.

Technicon Instrument Company (1965). N-3A Methodology for: Serum Calcium.

Technicon Instrument Company (1968). N-31P Methodology for Serum Calcium.

Varley, H. (1967). Practical Clinical Biochemistry, 4th ed., p. 438 Heinemann, London. 